\title{
Waste Management Plan for the Drilling Within the Chromium Plume West of 100-D/DR Reactors
}

\author{
Date Published \\ July 1997
}

\author{
Prepared for the U.S. Department of Energy \\ Office of Environmental Restoration \\ Bechtel Hanford, Inc. \\ Richland, Washington
}

\section{TRADEMARK DISCLAIMER}

Reference herein to any specific commercial product, process, or service by trade name, trademark, manufacturer, or otherwise, does not necessarily constitute or imply its endorsement, recommendation, or favoring by the United States Government or any agency thereof or its contractors or subcontractors.

Available to the U.S. Department of Energy and its contractors from Office of Scientific and Technical Information

P.O. Box 62

Oak Ridge, TN 37831

(615) 576-8401

Available to the public from the U.S. Department of Commerce 
National Technical Information Service

5285 Port Royal Road

Springfield, VA 22161

(703) $487-4650$

1.0 NTRODUCTION

2.0 DESCRIPTION

3.0 CONTAMINATION/FIELD MONITORING

3.1 DRILLING SPOILS MONITORING

3.2 WATER MONITORING

4.0 CONTAINMENT OF SPOILS AND WASTES

4.1 STORAGE CONTAINERS

4.2 STORAGE LOCATIONS

5.0 DISPOSAL OF DRILLING-GENERATED WASTES

6.0 REFERENCES

\section{FIGURES}

1. Approximate Locations for New Wells in the 100-D/DR Area

2. Interim Control Form for Unknown. Suspected Hazardous, Suspected Mixed, and Radioactive Waste

\subsection{INTRODUCTION}

This waste management plan (WMP) provides guidance for managing drilling spoils generated during the installation of groundwater wells in the 100-D/DR Area, which is part of the 100-HR-3 Operable Unit. The wells are being installed to meet two objectives (Connelly 1997):

(1) better define the nature and extent of a previously identified chromium plume in the area, and (2) act as groundwater extraction wells if the contamination warrants.

The new wells will be located in the vicinity of well 199-D4-1, which was installed in October 1996. That well was installed in response to the discovery of high concentrations of chromium in water samples from the aquifer beneath the shoreline and from riverbed sediments (Hope and Peterson 1996). 
This WMP was developed using the plan prepared for installing well 199-D4-1 (DOE-RL 1996) and other wells associated with an interim remedial measure to address chromium contamination. The drilling and construction spoils from installing the new wells are expected to be similar in characteristics to those from well 199-D4-1 because of the similarity in geologic and hydrologic setting and the contamination history for the area.

This WMP meets the substantive requirements for Site-Specific Waste Management Instructions as detailed in BHI-EE-10, Waste Management Plan.

\subsection{DESCRIPTION}

Four new wells are scheduled for installation during this project (199-D3-2, 199-D4-13, 199-D4-14, and 199-D4-15). Their locations are shown on the map in Figure 1. Based on the characteristics of well 199-D4-1 (Myers et al. 1996), each of the new wells will be drilled to approximately $100 \mathrm{ft}(30 \mathrm{~m})$ below ground surface (bgs). Drilling will proceed through Hanford gravels to a depth of approximately $55 \mathrm{ft}(17 \mathrm{~m}) \mathrm{bgs}$, and then through Ringold Formation Unit E sandy/gravelly sediments to the final drilled depth. Groundwater should be encountered at approximately $80 \mathrm{ft}(24 \mathrm{~m})$ bgs. Well screen (open) intervals will be placed between approximately 75 and $95 \mathrm{ft}(23$ and $29 \mathrm{~m})$ bgs.

\subsection{CONTAMINATION/FIELD MONITORING}

Based on the history of operations for the general area where the new wells will be drilled, soil column contamination is not expected to be encountered. During the installation of interim remedial measure wells in the 100-D/DR Area, neither chemical nor radiological contamination that required special procedures for worker safety and/or drilling spoils management was encountered (Myers et al. 1996), except for water containing hexavalent chromium from well 199-D4-1. Also, drilling during May 1997 for the In Situ Redox Manipulation (ISRM)

Treatability Test, which is in the vicinity of well 199-D4-1, has not produced drilling spoils that would be classified as regulated waste (unpublished field information). The waste management plan for the ISRM test drilling is described in BHI (1997). As a precaution, monitoring will be conducted at the new drilling sites to verify that unsuspected contamination is not present in soil and water drilling spoils that are produced.

\subsection{DRILLING SPOILS MONITORING}

The accumulation of drilling spoils will be surveyed for radioactivity once each day during drilling operations, if deemed necessary by the Environmental Restoration Contractor (ERC) radiological control engineer. Measurements will be made by a radiological control technician (RCT) using hand-held screening instruments. A sample of dry drilling spoils will be screened for hexavalent chromium, nitrate, and sulfate using Hach kit (TM Hach Company, Loveland, Colorado) methods. The sample will be collected from the spoils accumulation pile as drilling proceeds downward to a depth of approximately $1 \mathrm{~m}$ above the water table, as estimated in the field. The data will be used to verify that predicted concentrations are below levels of concern for 
waste management purposes.

Radioactivity screening during the drilling of well 199-D4-1 and subsequent well construction did not reveal contamination (Myers et al. 1996). Screening of spoils associated with the ISRM test (May 1997) near well 199-D4-1 has also not revealed the presence of radioactivity in either the dry spoils from above the water table or the moist spoils from beneath the water table.

Drilling spoils from above the water table are not expected to be contaminated by chromium or other chemical constituents. Two soil samples were collected from well 199-D4-1 at depths of approximately $1 \mathrm{~m}$ and $4 \mathrm{~m}$ above the water table. Analyses for hexavalent chromium revealed concentrations of less than $0.18 \mathrm{mg} / \mathrm{kg}$ (Connelly 1997). Although percent recovery estimates from the laboratory for the analyses were anomalously low, the results indicate concentrations lower than $1 \mathrm{mg} / \mathrm{kg}$.

Additional soil sampling results from the same general area support the inference that chromium contamination is not widespread in the soil. Soil samples were collected at the 1907-DR process sewer outfall structure, which is known to have discharged chromium-bearing effluent to the soils along the shoreline (the outfall is located approximately $130 \mathrm{~m}$ northwest of well 199-D4-1 at the shoreline, see Figure 1). Of the ten soil samples collected, hexavalent chromium was not detected in nine (Hope 1996). One sample showed detection at $0.5 \mathrm{mg} / \mathrm{kg}$, which is close to the detection limit for the analytical method used.

Background concentrations for total chromium in Hanford Site soils range between 2.9 and 33.2 $\mathrm{mg} / \mathrm{kg}$ (DOE-RL 1995). Most, if not all, of the chromium in background soils is assumed to be the less toxic and less mobile trivalent form. Background concentrations are associated with chromium-bearing basalt rock fragments.

\subsection{WATER MONITORING}

Water samples will be collected when the water table is first encountered during drilling. The samples will be filtered and analyzed for hexavalent chromium using Hach kit methods at the well site. The expected concentration for hexavalent chromium in groundwater in the vicinity of the four new wells is approximately $1,000 \mu \mathrm{g} / \mathrm{L}$ based on monitoring results from well 199-D4-1. However, hexavalent chromium analyses on water samples taken during drilling of that well and the ISRM test wells have indicated concentrations less than $80 \mu \mathrm{g} / \mathrm{L}$, suggesting that the drilling process may reduce hexavalent chromium to trivalent chromium. No other significant chemical contamination is expected, based on the ground water chemistry observed in well 199-D4-1 and upgradient well 199-D2-6, although nitrate is elevated slightly above the $45,000 \mu \mathrm{g} / \mathrm{L}$ drinking water standard $(58,400 \mu \mathrm{g} / \mathrm{L}$ and $84,400 \mu \mathrm{g} / \mathrm{L}$, respectively) (Peterson and Raidl 1997).

Radionuclide contamination is also not expected, based on water data from wells 199-D4-1 and 199-D2-6. Analyses for selected radionuclides were conducted on the initial water samples collected from well 199-D4-1. The results indicated low to nondetect levels of contamination and all were below the U.S. Environmental Protection Agency (EPA) maximum contaminant levels for drinking water. The results were: gross alpha $(0.99 \pm 0.81 \mathrm{pCi} / \mathrm{L})$, gross beta $(7.6 \pm 2.0$ 
$\mathrm{pCi} / \mathrm{L})$, and tritium $(438 \pm 230 \mathrm{pCi} / \mathrm{L})$.

The release criteria for water spoils generated during drilling operations are based on EPA maximum contaminant levels for drinking water (40 Code of Federal Regulations [CFR] 141 Subpart G) or the State of Washington's Model Toxic Control Act (Washington Administrative Code [WAC] 173-340) Method B concentrations for groundwater protection, whichever is more stringent. The release criterion for hexavalent chromium is $80 \mu \mathrm{g} / \mathrm{L}$. Water generated during drilling activities that exceeds these release criteria will be contained for future treatment. Water that does not exceed these criteria will be disposed to the ground surface.

\subsection{CONTAINMENT OF SPOILS AND WASTES}

Solid and liquid spoils produced during drilling will be managed in accordance with Bechtel Hanford, Inc. (BHI) procedures (BHI-EE-10, Section 3, "Waste Storage and Handling"). Drilling spoils that are dry (e.g., materials produced from above the water table) will be accumulated in piles near the point of generation until surveyed by the RCT. Free moisture may accumulate from drilling spoils that are produced after reaching the water table. If hexavalent chromium at concentrations above the release criteria is encountered in the first water samples collected upon reaching the water table, subsequent moist drilling spoils will be placed on plastic sheeting to prevent residual free moisture from being released to the ground. All moist drilling spoils produced will be transferred to approved storage containers and stored while awaiting final disposition.

Containment of decontamination rinsate will not be required providing that the downhole tools and equipment are wiped down to remove drilling residues prior to steam cleaning. Wiping will be sufficient to remove all visible drilling residues. Steam cleaning will be done using potable water that does not contain additives. At the discretion of the Environmental Restoration Contractor Radiological Control Engineer, a radiological survey of tools and equipment will be conducted after they are wiped down to verify that no radiological contamination is picked up during steam cleaning, per BHI procedures (BHI-EE-01).

\subsection{STORAGE CONTAINERS}

When solid and liquid drilling spoils do not meet release criteria, the wastes will be placed in steel 55-gal (208-L) open-head drums, approved water tanks, or tanker trucks. Drums are to be filled to no more than $80 \%$ of capacity. A label will be attached to the lid and maintained in a legible condition until the Interim Control (IC) Form (see below) is attached to the container. The following information will be written on the label using indelible contrasting ink:

- Project name (e.g., 100-D/DR Area Drilling)

- Borehole number

- Drilling interval (footage)

- Contents and reason for containment

- Date sealed

- Unique container number (provided by Environmental Restoration Waste Management) 
- Contact information.

The unique container number will be placed on the container lid at the time of initial sealing and maintained in a legible condition until disposal of the container contents. Unique container number legibility will be monitored during routine waste storage site inspections.

An IC Form (see Figure 2) will be completed and attached to the side of the container. The IC Form is filled out by the Field Engineer and provides pertinent information that is specific to the individual container. A copy of the completed IC Form will be forwarded to Environmental Restoration Waste Management for waste inventory tracking purposes.

\subsection{STORAGE LOCATIONS}

Containers of contaminated drilling spoils may be staged temporarily at active drilling sites, near the point of generation. Containers will be elevated off the ground using pallets. Following active drilling operations, containers will be consolidated at a storage site located directly north of the 105-D Reactor Building (see Figure 1).

Containers holding free liquid (i.e., water wastes, saturated soil materials) that are to be stored outside during freezing weather conditions will be overpacked, preferably in 95-gal (360-L) reusable poly overpacks. The unique container number of the original drum will be displayed on the overpack. Containers at the consolidated waste storage site will be routinely inspected, along with other previously generated 100-HR-3 Operable Unit waste materials.

\subsection{DISPOSAL OF DRILLING-GENERATED WASTES}

Dry drilling spoils are not expected to require extended waste management. Uncontaminated spoils will be distributed to the ground in the vicinity of the well. If contaminated drilling spoils are generated, they will be packaged as required to meet the Environmental Restoration Disposal Facility (ERDF) waste acceptance criteria. This may require processing in addition to the dewatering that occurs during temporary storage on plastic sheeting at the drilling site. The remaining solids will be disposed to ERDF.

The Toxicity Characteristic Leaching Procedure (TCLP), which is contained in Appendix II of 40 CFR Part 261, describes concentration limits for contaminants in liquid extracts derived from solid wastes. The limit for total chromium in the liquid extract is $5,000 \mu \mathrm{g} / \mathrm{L}$. The free moisture from drilling spoils is unlikely to exceed that concentration, so the drilling spoils are not likely to qualify as dangerous waste (WAC 173-303-090).

Chromium is the only contaminant expected in moist drilling spoils. Any water that exceeds release criteria will be temporarily stored and processed at a future date using the 100-HR-3 interim remedial measure treatment system, which is located in the 100-H Area. If other contaminants are encountered, the water waste will be managed in accordance with ERC purgewater handling procedures (BHI-EE-01).

Miscellaneous trash items (e.g., rags, equipment wipedown residue, disposable protective 
equipment) are not expected to contain radiological and/or chemical contamination at levels that are regulated. Accordingly, they will be disposed of as nonradioactive, nondangerous waste. If radiological and/or chemical contamination is encountered, then the trash will be contained and disposed appropriately.

\subsection{REFERENCES}

BHI-EE-01, Environmental Investigations Procedures, Bechtel Hanford, Inc., Richland, Washington.

BHI-EE-10, Waste Management Plan, Bechtel Hanford, Inc., Richland, Washington.

BHI, 1997, In Situ Redox Manipulation Treatability Test--Waste Management Plan, BHI-00986, Rev. 0, Bechtel Hanford, Inc., Richland, Washington.

Connelly, M. P., 1997, Assessment of the Chromium Plume West of the 100-D/DR Reactors, BHI-00967, Rev. 1, January 1997, Bechtel Hanford, Inc., Richland, Washington.

DOE-RL, 1995, Hanford Site Background: Part I, Soil Background for Nonradioactive Analytes, DOE/RL-92-24, Rev. 3, U.S. Department of Energy, Richland, Washington.

DOE-RL, 1996, 100-HR-3 Operable Unit Drilling Waste Management Plan, DOE/RL-96-58, Rev. 0, U.S. Department of Energy, Richland, Washington.

Hope, S. J., 1996, 1907-DR Process Sewer Outfall Site Soil Characterization, BHI-00860, Rev. 0, Bechtel Hanford Inc., Richland, Washington.

Hope, S. J. and R. E. Peterson, 1996, Chromium in River Substrate Pore Water and Adjacent Groundwater: 100-D/DR Area, Hanford Site, Washington, BHI-00778, Rev. 0, Bechtel Hanford, Inc., Richland, Washington.

Myers, D. A., V. M. Johnson, M. Melhorn, and L. D. Walker, 1996, Well Summary Report: 100-HR-3 and 100-KR-4 Interim Remedial Action Wells, BHI-00953, Rev. 0, Bechtel Hanford, Inc., Richland, Washington.

Peterson, R. E. and R. F. Raidl, 1997, "FY 1997 Updates to Contaminant Plume Maps and Conceptual Site Models: 100-KR-4 and 100-HR-3 Operable Units," Interoffice Memorandum, M. H. Sturges to A. J. Knepp, CCN 044750.

WAC 173-303, 1993, "Dangerous Waste Regulations," Washington Administrative Code, as amended.

WAC 173-340, 1992, "Model Toxics Control Act Cleanup Regulation," Washington Administrative Code, as amended. 